\title{
PENAMBANGAN BATU SPLIT YANG MENYISAKAN KELERENGAN TERJAL DI DAERAH AWANGBANGKAL, KECAMATAN KARANGINTAN, KABUPATEN BANJAR, PROVINSI KALIMANTAN SELATAN
}

\author{
Jarwanto $^{1)}$ \\ ${ }^{1}$ Jurusan Teknik Pertambangan, Akademi Teknik Pembangunan Nasional, Banjarbaru, \\ Kalimantan Selatan. \\ Email : jarwanbjb@gmail.com
}

\begin{abstract}
Mining of split rock or ultramafic igneous rock, located in the Awangbangkal area, Karangintan District, Banjar Regency, South Kalimantan Province, causes steep slopes. The formation of the Meratus Mountains is an oceanic bedrock that is exposed to the earth's surface and is mined by local residents using simple tools or semi-mechanical equipment carried out by the company. Positive impacts arise but negative impacts will also build up over time. Day by day more dangerous slopes were formed. The local government became worried because it was dangerous. This writing is compiled based on the results of direct measurements in the field using the Theodolith unit. The measurement results are processed using Autocad Landesktop 2009 software. The analysis is by classifying the slope of the formed slopes according to the data that is already in digitized form. The result is a dangerous area on the east side, because it has a slope of $25 \%-45 \%$ (steep). Although from a geological point of view this area is stable because it is formed by igneous rocks, from the local government side this is a concern for the people who do work in the area.
\end{abstract}

Keyword : Peridotit, Autocad Landesktop 2009, Slope 25\%-45\%.

\section{PENDAHULUAN}

Lokasi penelitian berada di wilayah Kabupaten Banjar, Provinsi Kalimantan Selatan seperti yang terlihat pada Gambar 1. Lokasi berada pada wilayah Desa Awangbangkal barat, Kecamatan Karangintan, Kabupaten Banjar, Provinsi Kalimantan Selatan. Batas titik koordinat penelitian berada pada $114^{\circ}$ $57^{\prime} 57,15$ hingga $114^{\circ} 58^{\prime} 31,24^{\prime \prime} \mathrm{BT}$, dan $3^{\circ} 29^{\prime}$ 14,01 " hingga $3^{\circ} 30^{\prime} 6,44^{\prime}$ " LS. Sangat mudah terjangkau dengan kendaraan roda empat. Hanya memerlukan waktu setengah jam dari Ibukota Kabupaten Banjar di Martapura, maupun akses dari Airport Syamsudin Noor di Banjarbaru, Kalimantan Selatan.

Morfologi daerah penelitian terbentuk dari batuan yang menonjol cukup tinggi di bagian timur dan mempunyai kelerengan landai di bagian barat. Secara regional daerah setempat merupakan areal yang cukup menonjol sebagai batuan dasar dari Pegunungan Meratus yang saat ini dalam pengusulan Geopark Nasional Pegunungan Meratus.
Akibat dari melimpahnya batu split dan pembangunan fisik yang berlangsung, munculah konsesi tambang-tambang quarry yang ada di Kalimantan Selatan terutama di Kabupaten Banjar yang lokasinya cukup strategis, dekat dengan jalan atau akses keluar dan sudah merupakan jalan yang permanen. Akibat penambangan tersebut, muncullah masalah baru, yaitu kelerengan yang terjal sehingga sangat berbahaya bagi aktifitas di sekitar lokasi kegiatan. Kelerengan ini dikelompokkan berdasarkan akibat yang ditimbulkan oleh kegiatan sehingga menjadikan bentukan kelerengan seperti saat ini. Menurut William D Thornburry 1969 yang dipadukan dengan R.A van Zuidam, 1983 (dalam Harjowigeno, 1995), dan didasarkan pada Pedoman Penyusunan Pola Rehabilitasi Lahan dan Konservasi Tanah (1986) sebagai acuan dalam pengelompokan kelerengan, kondisi lahan sebagian sudah berada pada kategori curam.

Perhitungan kelerengan didapat dari hasil pengukuran lapangan dengan mengacu pada 
penggunaan software Autocad landesktop 2009 dipadukan dengan Peta Rupa Bumi Lembar Martapura 1712-52 dan Lembar Aranio 1712-24 skala $1: 50.000$. Saat pengambilan data di lapangan mengacu pada Pengertian Ilmu Ukur Tanah yang ditulis D. Adi 2015. Proses transfer data lapangan hingga terbentuk kontur dipandu oleh tutorial dari Widigdyono 2017 . Darius Puas, 2010 lebih detail dalam pembuatan penampang melintang dalam menggunakan Software Autocad Landesktop 2009.

Tujuan penelitian ini untuk pengklarifikasian kemiringan lereng dan erat hubungannya dengan kondisi lapangan termasuk bahaya dan tidaknya area yang dipetakan dan penentuan area yang tidak berbahaya. Selain itu juga untuk informasi dan feedback kepada pemerintah daerah setempat akan kondisi sekarang ini, hal ini dikaitkan dengan informasi dari penduduk akan bahaya dari kondisi kerja dan lingkungan yang ada. Kegiatan pengambilan batuan di area ini telah berlangsung selama bertahun-tahun, hingga akhirnya areal ini menjadi areal yang nyaris tidak diketemukan tanah atau batuan yang telah lapuk. Situasi terakhir, kegiatan penambangan yang dilakukan secara manual maupun secara semi mekanis menjadikan bagian tebing yang curam menjadi lebih curam lagi dari tahun ke tahun. Konsesi yang diberikan oleh pemerintah daerah setempat menjadikan areal ini sarat dengan kepentingan bisnis batuan "split" menjadi semakin marak

Menurut Peta Geologi Lembar Banjarmasin 1720 edisi 1994, area penelitian yang mempunyai luas 104,72 ha (lingkup garis merah pada Gambar 2) ini didominasi seluruhnya oleh Batuan Ultra Mafik berupa Peridotit (Sukandarrumidi, 2009). Batuan ini mendominasi formasi yang dibentuk oleh batuan Pratersier. Menitik dari batuan dasar merupakan batuan beku ultra basa, sangat memungkinkan terbentuknya morfologi yang resisten terhadap kondisi segala cuaca. Di beberapa bagian merupakan areal yang cukup landai, namun pada bagian lain merupakan bagian yang menjulang dan mempunyai perbedaan ketinggian keduanya lebih kurang 100 meter.

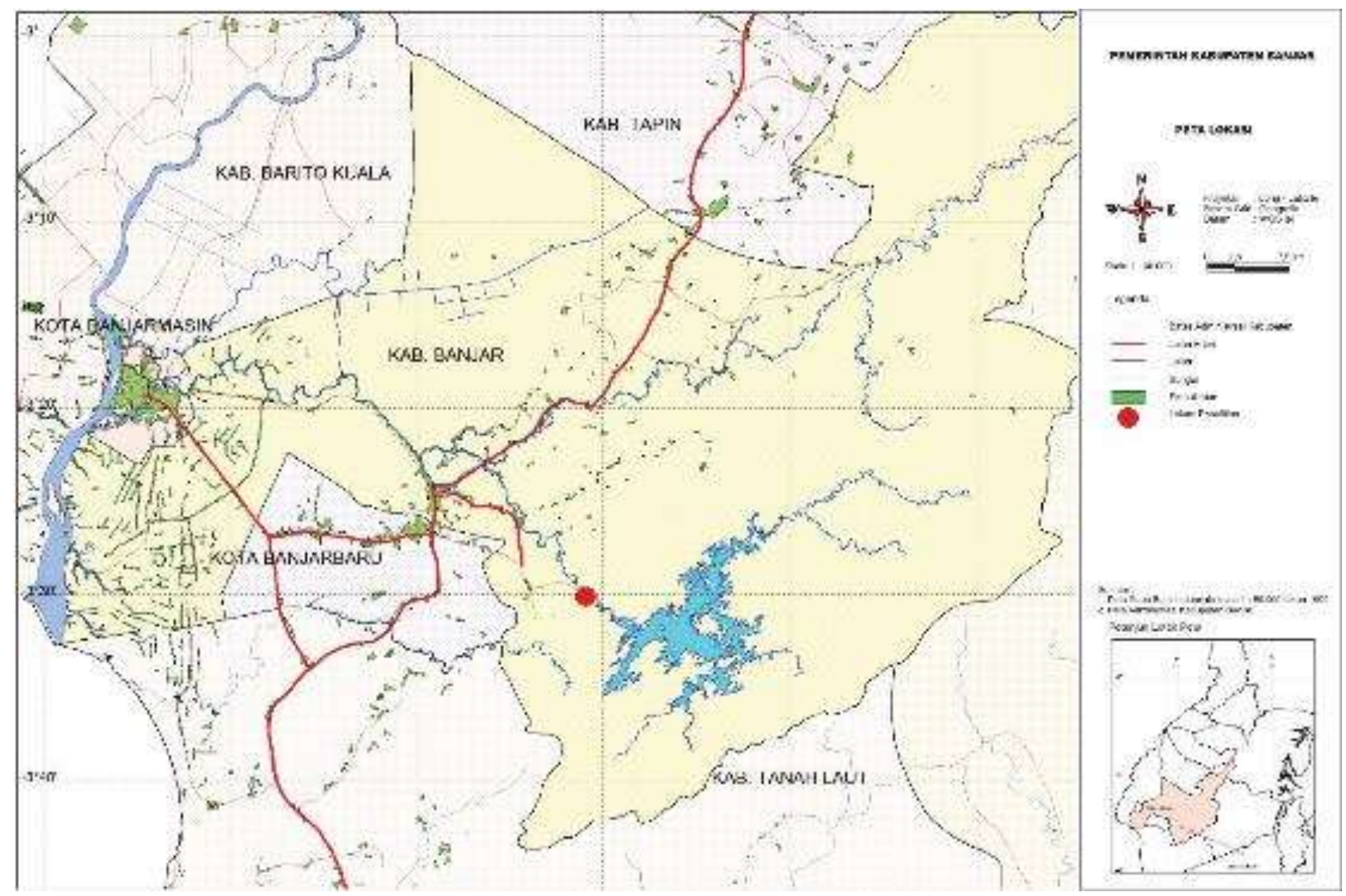

Gambar 1. Letak lokasi Penelitian terhadap Wilayah Kabupaten Banjar. 
Seperti yang terlihat pada Gambar 2, Peta Geologi yang dibentuk oleh formasi batuan Pratersier, namun pada arsir warna biru (bagian timur) terdapat kegiatan penambangan yang mempunyai kemiringan lereng terjal dengan resistensi batuan yang lebih kuat. Pada area ini fokus penelitian disusun.

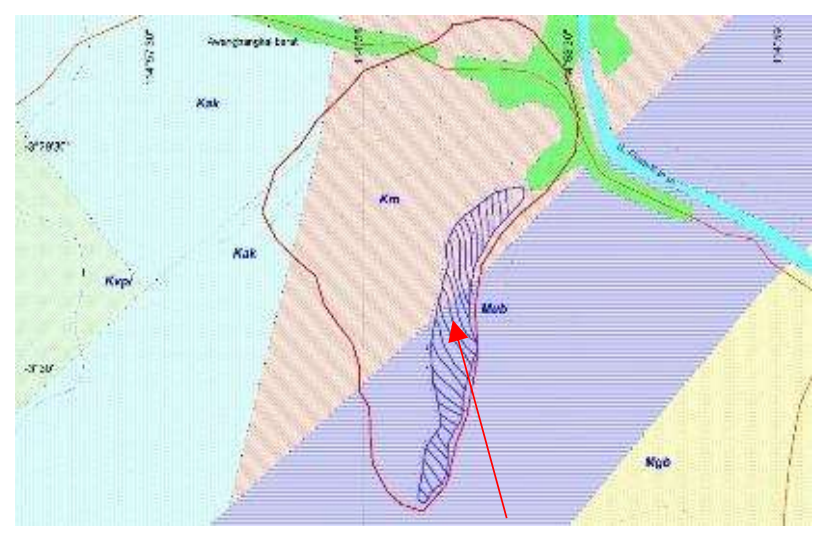

Gambar 2. Area penelitian menurut Peta Geologi.

Parameter yang digunakan untuk menentukan kelerengan adalah seperti Tabel 1 berikut :

Tabel 1. Klasifikasi kelerengan (Disarikan dari Pedoman Penyusunan Pola Rehabilitasi Lahan dan Konservasi Tanah (1986))

\begin{tabular}{|c|c|c|}
\hline KELAS & $\begin{array}{c}\text { KEMIRINGAN } \\
(\%)\end{array}$ & KLASIFIKASI \\
\hline I & $0-8$ & DATAR \\
\hline II & $>8-15$ & LANDAI \\
\hline III & $>15-25$ & AGAK CURAM \\
\hline IV & $>25-45$ & CURAM \\
\hline V & $>45$ & SANGAT CURAM \\
\hline
\end{tabular}

Sebagai bagian dari lahan milik Kementerian Kehutanan RI, juga dilakukan pendekatan berdasar peraturan di Kementerian Kehutanan, sehingga akan menghasilkan skor seperti Tabel 2.

Tabel 2. Skor kemiringan lereng.

\begin{tabular}{|l|c|c|c|}
\hline Kelas & $\begin{array}{c}\text { Kemiringan } \\
\text { Lereng } \\
(\boldsymbol{\%})\end{array}$ & Skor & $\begin{array}{c}\text { Skor } \mathbf{x} \\
\text { Bobot } \\
(\mathbf{2 0})\end{array}$ \\
\hline Datar & $<$ & 5 & 100 \\
\hline Landai & 8 & 4 & 80 \\
\hline Agak & 16 & 3 & 60 \\
\hline Curam & 26 & 2 & 40 \\
\hline SangatCura & $>$ & 1 & 20 \\
\hline
\end{tabular}

Sumber: Peraturan Departemen Kehutanan No.P.4/ VSET/2013

\section{METODE PENELITIAN}

Metode penelitian dimulai dari kegiatan lapangan dengan acuan Peta Topografi menggunakan Peta Rupa Bumi Lembar Martapura 1712-52 dan Lembar Aranio 1712-24 skala 1 : 50.000 Edisi 1991. Pemetaan lapangan menggunakan unit theodolith yang digunakan sebagai sarana guna mengumpulkan data di lapangan yang merupakan sarana pengumpulan data dengan metode secara terestris (Adi D, 2015). Pembuatan kontur dari data theodolith mengacu dari Widigdyono, 2017 pada Buku Panduan Autocad Civil 3D Landesktop Companion 2009 yang dapat membentuk peta kelerengan berdasar sudut derajat hingga didapatkan prosentase kelerengan. Penampang melintang diselaraskan dengan metode yang dikemukakan oleh Darius Puas, 2010 yang menekankan aspek detail bagian-bagian pada relief secara 2 dimensi maupun 3 dimensi. Bentuk kelerengan dan penyusunan penampang merupakan bahan untuk digunakan sebagai analisis kelerengan agar tercipta rekomendasi.

Prosentase kelerengan yang telah dikategorikan menurut William D Thornburry 1969 yang dipadukan dengan R.A van Zuidam, 1983 (dalam Harjowigeno, 1995) kemudian dimasukkan dalam klasifikasi menurut Pedoman Penyusunan Pola Rehabilitasi Lahan dan Konservasi Tanah (1986). Sedangkan skor menggunakan Peraturan Departemen Kehutanan No.P.4/VSET/2013. Diagram 1 merupakan diagram yang menggambarkan metode yang digunakan dalam penyusunan penelitian ini.

\section{Kegiatan Lapangan dan Penyusunan Peta}

Wilayah yang dilakukan penelitian ini memiliki topografi yang mudah berubah dari hari ke hari akibat kegiatan penambangan, sehingga perlu satu waktu pelaksanaan penelitian. Data topografi diambil langsung di lapangan menggunakan unit Theodolith manual berupa Sokkia Set 5 C. Pemetaan topografi memerlukan waktu selama 3 minggu lebih, namun kadang akan kembali ke lapangan karena ada beberapa bagian yang belum ter-cover. Titik tertinggi berada di ketinggian 131,2 meter di atas permukaan laut. Sedangkan titik terendah berada pada posisi 42,2 meter di atas permukaan laut.

Visual di lapangan seperti pada foto 1 dengan menempatkan unit Theodolith berada pada ketinggian 125,2 meter diatas permukaan laut, sedangkan pada sisi kanan merupakan bagian bawah 


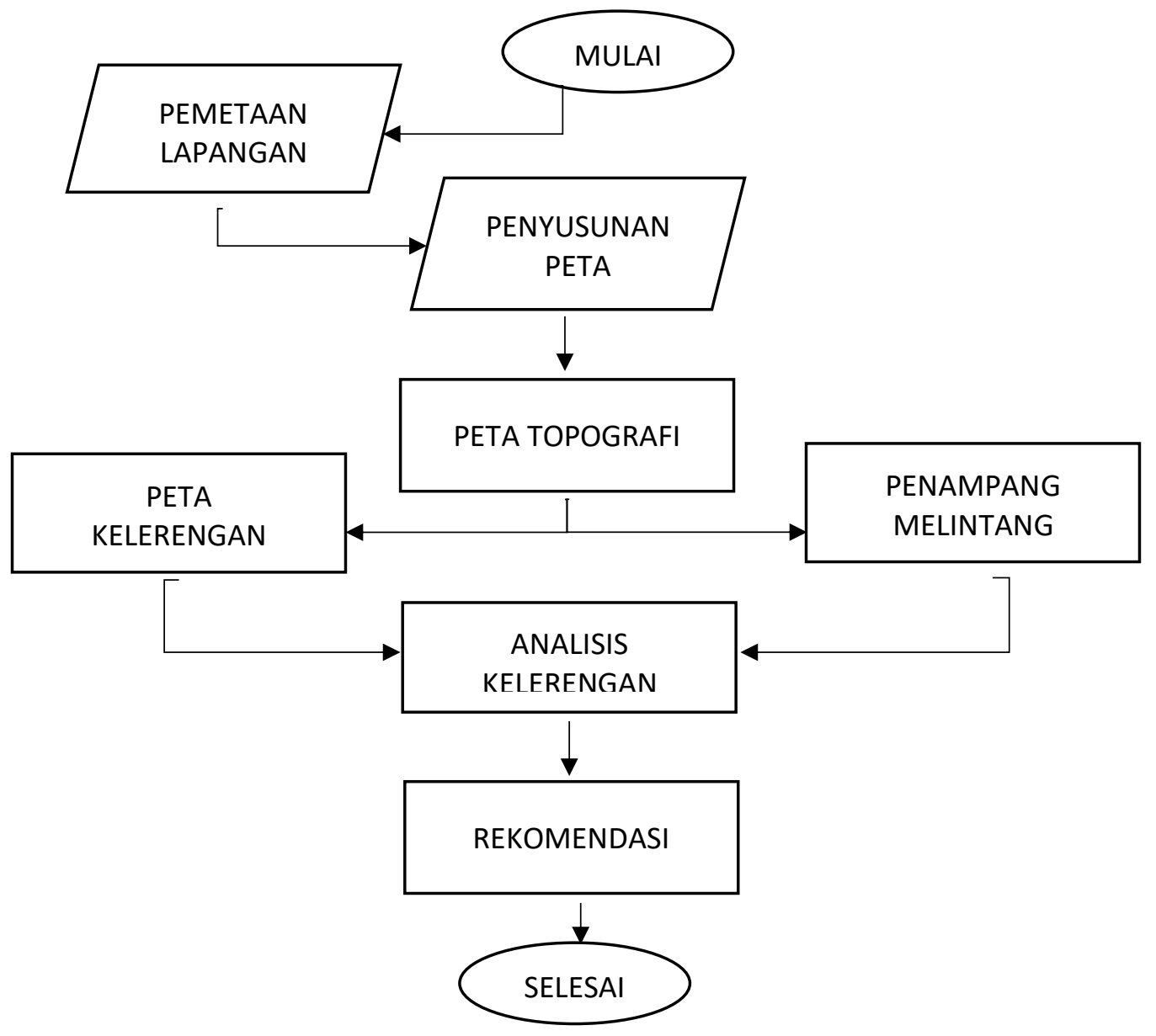

Diagram 1. Diagram Alir Penelitian

dengan ketinggian 51 meter diatas permukaan laut. Perbedaan ketinggian inilah yang diukur prosentase kelerengannya.

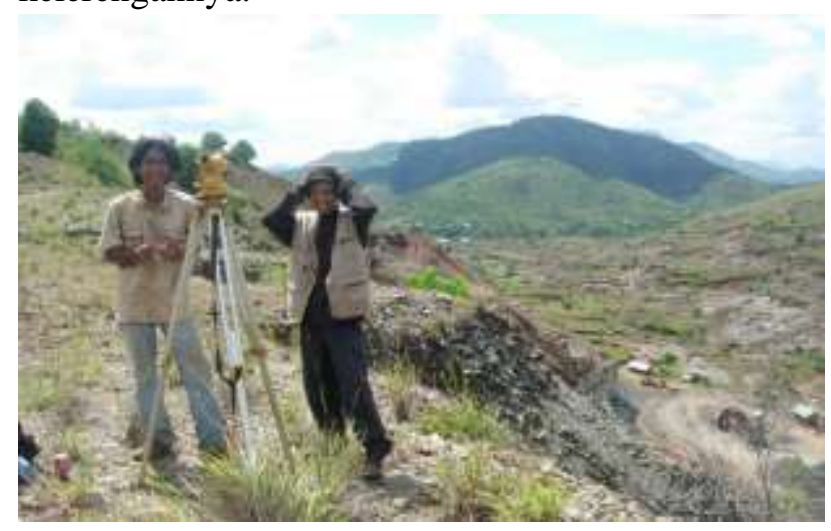

Foto 1. Foto saat pemetaan lapangan yang memperlihatkan kelerengan cukup terjal. Sisi kanan foto terlihat unit chrusher, truck, rumah dan excavator, sebagai bagian peralatan pekerjaan untuk penggalian peridotit di area kerja.Hasil shoot lapangan menggunakan unit Theodolit Sokkia mendapatkan 1606 titik koordinat. Kegiatan lapangan selama 3 minggu dan kadang-kadang kembali lapangan karena perlu data tambahan dari beberapa bagian yang belum ter-cover letak koordinatnya. Contoh hasil koordinat di lapangan seperti pada Tabel 3 yang memperlihatkan 14 titik dari 1606 titik yang didapatkan.

Data lapangan yang telah selesai selanjutnya ditransfer ke dalam bentuk data koordinat yang dapat memunculkan koordinat $\mathrm{x}, \mathrm{y}$ dan $\mathrm{z}$. $\mathrm{x}$ yaitu : $\mathrm{x}$ bujur, y lintang dan $\mathrm{z}$ merupakan ketinggian. Seperti yang dijelaskan dalam Buku Autocad Civil 3D Landesktop Companion 2009 oleh Widigdyono 2017, titik-titik koordinat diubah ke bentuk PNEZD. P berupa nomor urut, E berupa Easting atau bujur, $\mathrm{N}$ berupa Northing atau lintang, $\mathrm{Z}$ adalah elevasi yang dihitung dari permukaan air laut dan D adalah Deskripsi berupa keterangan.

Titik - titik yang sduah terbentuk dalam format P, E, $\mathrm{N}, \mathrm{Z}$ dan D ditransfer ke dalam software Autocad Landesktop 2009 sehingga dalam program tersebut titik-titik koordinat menempati alokasi sesuai 
koordinatnya seperti yang terlihat pada Gambar 3. Data yang berada di luar area tetap menjadi data yang diperlukan karena merupakan data pendukung untuk pembuatan kontur nantinya.

Langkah selanjutnya adalah pembuatan kontur yang hasilnya seperti yang tertera pada Gambar 4 . Titik-titik ini dimasukkan ke dalam area dan dilanjutkan dengan pembuatan kontur. Kontur yang menggambarkan garis-garis virtual yang mempunyai ketinggian yang sama. Garis yang terbentuk merupakan garis khayal yang menghubungkan titiktitik yang mempunyai ketinggian yang sama.

Titik kordinat yang telah di-overlay dengan peta dasar dan dipadukan dengan google map didapatkan titik-titik hasil pengukuran lapangan. Selanjutkan disusun pembuatan garis kontur. Titik titik koordinat dapat ditampilkan pada peta yang telah di-overlay atau tumpang tindihkan pada peta dasar maupun hasil potret dari google map. Peta kontur dapat terbentuk dengan tampilan yang telah di overlay dengan google map.

Tabel 3. Koordinat hasil lapangan.

\begin{tabular}{|r|c|r|r|c|}
\hline Number & Easting & Northing & \multicolumn{2}{|c|}{ Elevation Raw Desc } \\
\hline 205 & $274,423.8$ & 9612515.4 & 116.2 & $\mathrm{x}$ \\
\hline 206 & $274,471.0$ & 9614079.0 & 48.3 & 473 \\
\hline 207 & $274,446.0$ & 9613959.0 & 50.3 & 474 \\
\hline 208 & $274,430.1$ & 9612510.8 & 116.2 & $\mathrm{x}$ \\
\hline 209 & $274,295.0$ & 9613819.0 & 60.6 & 476 \\
\hline 210 & $274,206.0$ & 9613733.0 & 66.9 & 477 \\
\hline 211 & $274,434.4$ & 9612515.2 & 116.2 & $\mathrm{x}$ \\
\hline 212 & $274,433.0$ & 9612523.4 & 116.2 & $\mathrm{x}$ \\
\hline 213 & $274,431.4$ & 9612530.0 & 116.2 & $\mathrm{x}$ \\
\hline 214 & $274,508.0$ & 9614007.0 & 50.3 & 481 \\
\hline 215 & $274,493.0$ & 9613915.0 & 56.3 & 482 \\
\hline 216 & $274,430.8$ & 9612535.8 & 116.2 & $\mathrm{x}$ \\
\hline 217 & $274,437.3$ & 9612547.1 & 116.2 & $\mathrm{x}$ \\
\hline 218 & $274,604.0$ & 9613707.0 & 47.3 & 485 \\
\hline
\end{tabular}

Hasil yang didapatkan dari pembuatan kontur seperti yang terihat pada Gambar 5. Pada gambar ini peta dasar dari Google Map tidak ditampilkan. Hal ini dilakukan agar tampilan terlihat rapi untuk selanjutnya dapat dilakukan analisa peta dari bentukan kontur yang telah dibuat.

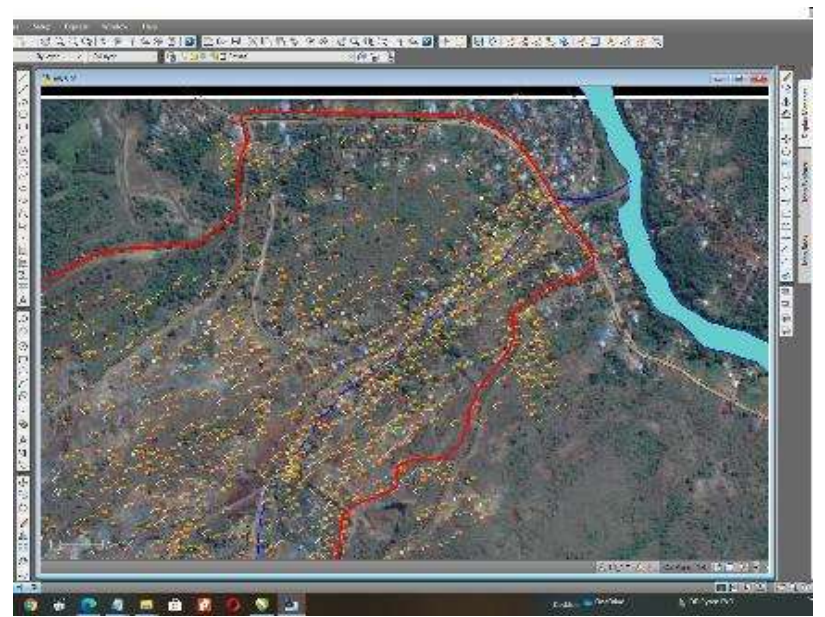

Gambar 3. Titik koordinat yang sudah ditransfer ke dalam Autocad Landesktop 2009.

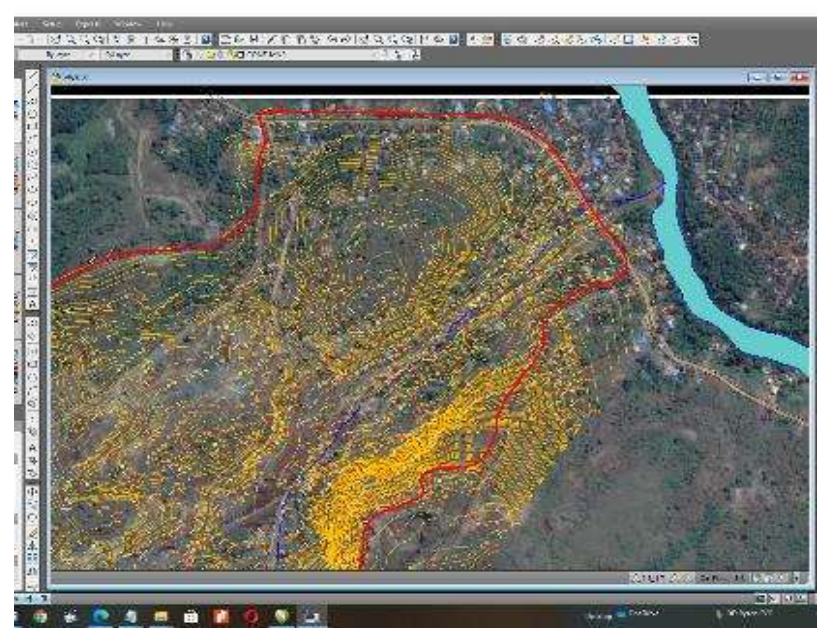

Gambar 4. Kontur yang telah terbentuk dari titiktitik koordinat yang telah dimasukkan dalam Software Autocad Landesktop 2009

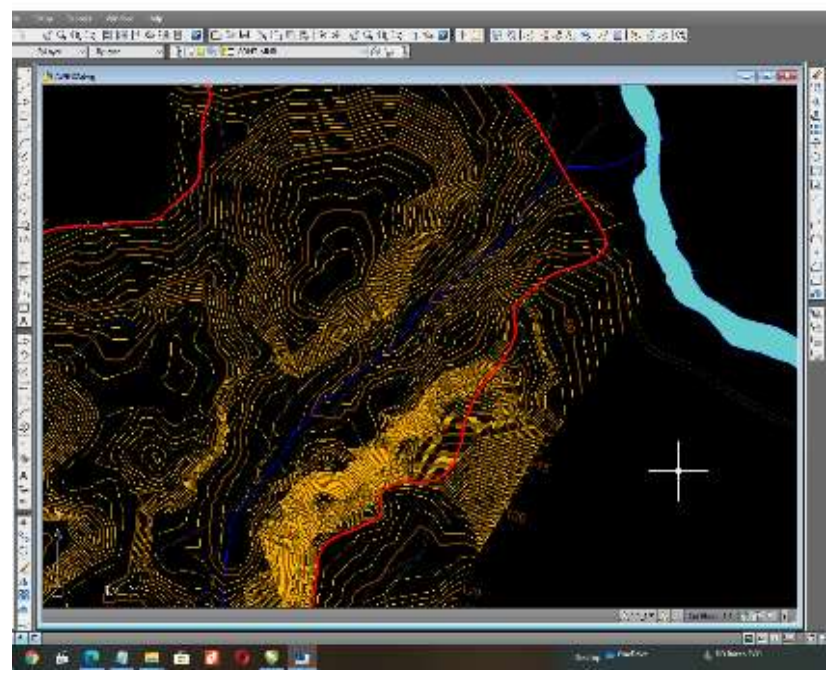

Gambar 5. Peta Topografi yang terbentuk dengan kontur yang mempunyai ketinggian 
Data yang sudah siap dibuat menjadi kontur yang mempunyai ketinggian yang dihitung di atas permukaan laut sehingga terbentuklah peta Topografi, Peta Kelerengan dan Penampang Melintang. Analisis dilakukan dengan mendekatkan beberapa parameter untuk dapat dilakukan pengelompokan beberapa hasil perhitungan (Darius Puas, 2010).

Pada Peta Topografi yang menggambarkan garis-garis virtual yang mempunyai ketinggian yang sama dibuat liniasi untuk keperluan penampang melintang. Garis liniasi tersebut seperti yang ditunjukkan pada Gambar 6. Ada 3 garis dengan nama Penampang A, Penampang B dan penampang C. Garis ini merupakan garis yang dapat mewakili bagian-bagian dengan posisi tinggi dan rendah

Hasil dari penampang A, B dan C dapat dilihat pada Gambar 7 yang ditampilkan dalam 2 dimensi dari samping. Menghasilkan profil yang diharapkan mewakili lokasi yang mempunyai titik yang tinggi dan titik yang cukup rendah. Dari profil tersebut dapat dibuat kemiringan yang terbentuk. Kemiringan yang telah didapatkan dibuat pengelompokan sehingga analisa mudah untuk dilakukan.

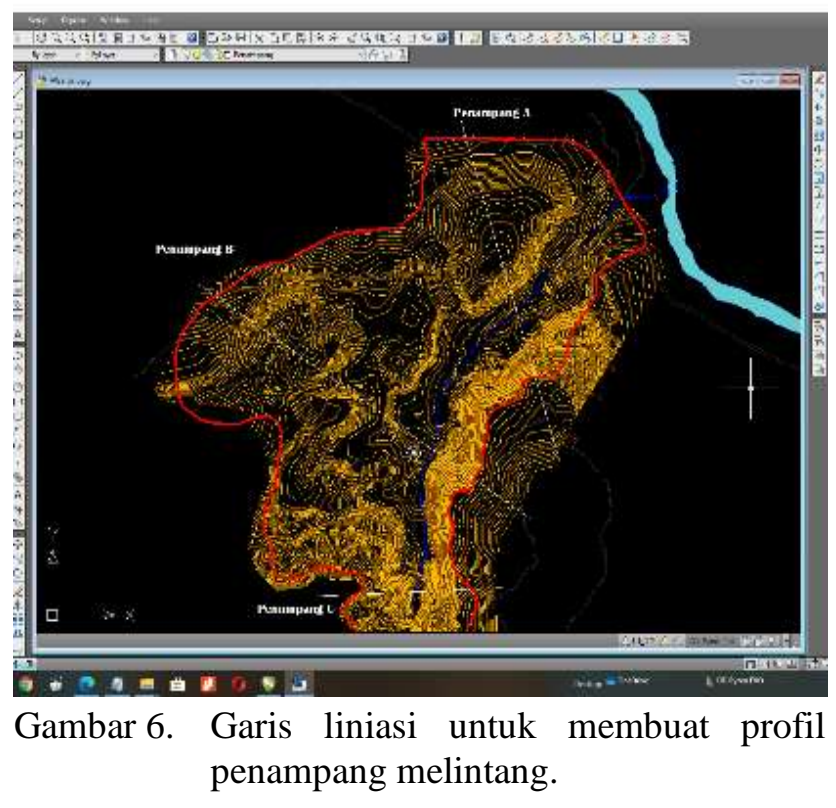

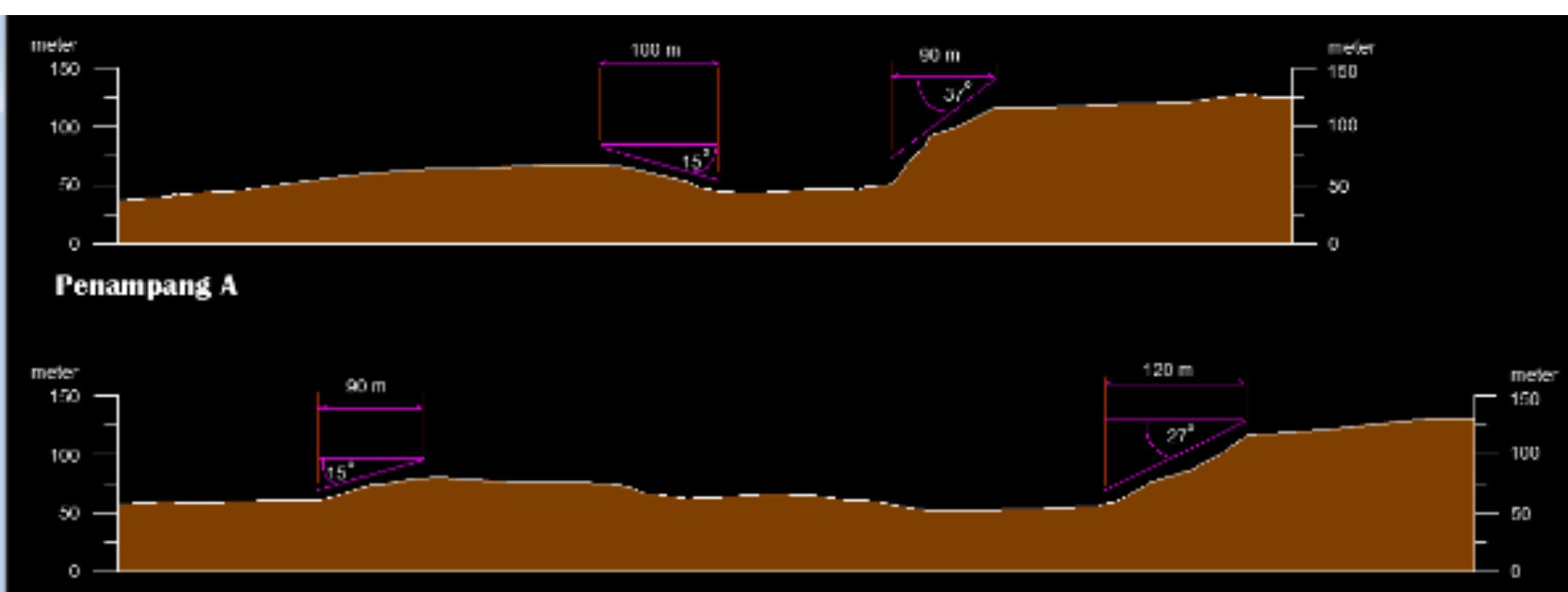

Penampang Is

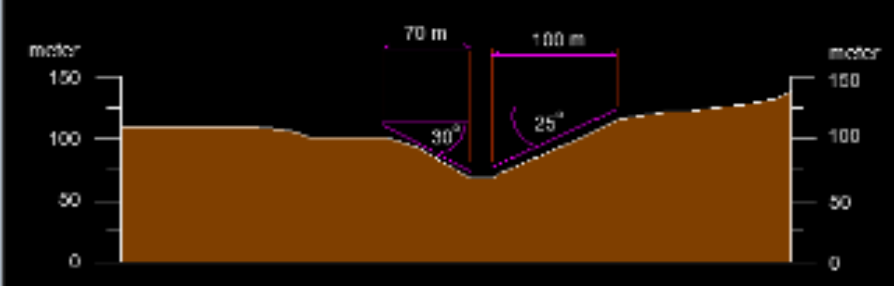

Penampang C

Gambar 7. Penampang melintang yang telah terbentuk yang menggambarkan kelerengan yang curam maupun landai. 


\section{HASIL DAN PEMBAHASAN}

\section{Analisis Kelerengan}

Kemiringan (slope) dapat ditentukan dengan menentukan interval kontur, beda tinggi dan beberapa parameter lain sehingga dapat emnghitung besar sudut kemiringan dan kelerengan.

Kemiringan didapatkan dengan cara umum yaitu :

$\tan \alpha=\frac{\text { beda tinggi }(m)}{\text { jarak horizontal }(m)}$

Dengan demikian derajat kemiringan adalah :

$\square^{\mathrm{o}}=\arctan \square \square$

Sedangkan prosentase kemiringan diperoleh dengan cara :

$\%$ kemiringan $=$ derajat kemiringan $\times 100 \%$

Sebagai contoh hasil perhitungan :

Beda tinggi : 65 meter

Jarak Horizontal sebenarnya : 94 meter

$\tan \alpha=\frac{\text { beda tinggi }(m)}{\text { jarak horizontal }(m)}$.

$\tan \alpha=\frac{65(\mathrm{~m})}{94(\mathrm{~m})}$

$\operatorname{Tan} \alpha=0.6915$

$$
\begin{aligned}
\alpha \quad & =\arctan 0.6915 \\
& =34,663^{\circ}
\end{aligned}
$$

Prosentase : $\left(34,663^{\circ} / 90^{\circ}\right) \times 100 \%=38,51 \%$

Dari contoh dan perhitungan yang sama disusun dengan semua nilai-nilai dimasukkan dalam rumus tersebut sehingga menjadi area yang telah terpetakan seperti Gambar 8. Semua area di dalam liniasi garis merah dibuat satu persatu nilai kelerengannya, dan dikelompokkan warna atau simbol. Area yang diarsir dan warna yang dibedabedakan untuk memudahkan dalam analisa. Pada bagian timur terlihat titik-titik warna merah yang mempunyai kemiringan curam. Dalam visual pada peta terbentuk dari rapatnya kontur (Widigdyono, 2017).

Bila dilihat dari gambar 3 dimensi dapat dilihat pada gambar 9 yang diadopsi dari Soffware Global Mapper, kemiringan yang curam dan berada dalam liniasi garis merah berada di sisi timur dan berwarna hitam.

Mengacu pada William D. Thornbury, 1969 dan R.A. van Zuidam, 1983 (dalam Harjowigeno, 1985), kelerengan yang terbentuk akibat perubahan

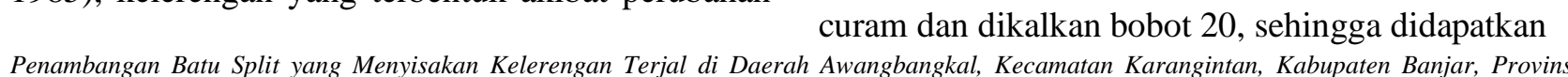
Kalimantan Selatan (Jarwanto) bentangalam dengan klasifikasi datar hingga sangat curam. Sedangkan hasil dari klasifikasi lereng yang disarikan dari Pedoman Penyusunan Pola Rehabilitasi Lahan dan Konservasi Tanah (1986) dapat ditampilkan seperti Tabel 4 berikut. Pada tabel ini didapatkan kemiringan antara 25 hingga $45 \%$ adalah klasifikasi curam dengan luas area sebesar $19,3 \mathrm{Ha}$ atau $18,43 \%$ dari luas liniasi garis merah pada peta.

\begin{tabular}{|c|c|c|c|c|c|}
\hline \multirow{2}{*}{$\begin{array}{l}\text { WARNA/ } \\
\text { SIMBOL }\end{array}$} & \multirow{2}{*}{ KELAS } & \multirow{2}{*}{$\begin{array}{c}\text { KEMIRINGAN } \\
(\%)\end{array}$} & \multirow{2}{*}{ KLASIFIKASI } & \multicolumn{2}{|c|}{ LUAS AREA DI PETA } \\
\hline & & & & (Ha) & (\%) \\
\hline & 1 & $0-8$ & DATAR & 34.01 & 32.48 \\
\hline & ॥ & $>8-15$ & LANDAI & 23.54 & 22.48 \\
\hline & III & $>15-25$ & AGAK CURAM & 27.87 & 26.61 \\
\hline & IV & $>25-45$ & CURAM & 19.3 & 18.43 \\
\hline & V & $>45$ & SANGAT CURAM & 0 & 0 \\
\hline & & & & 104.72 & 100 \\
\hline
\end{tabular}

Tabel 4. Klasifikasi Kemiringan Lereng Hasil Analisa

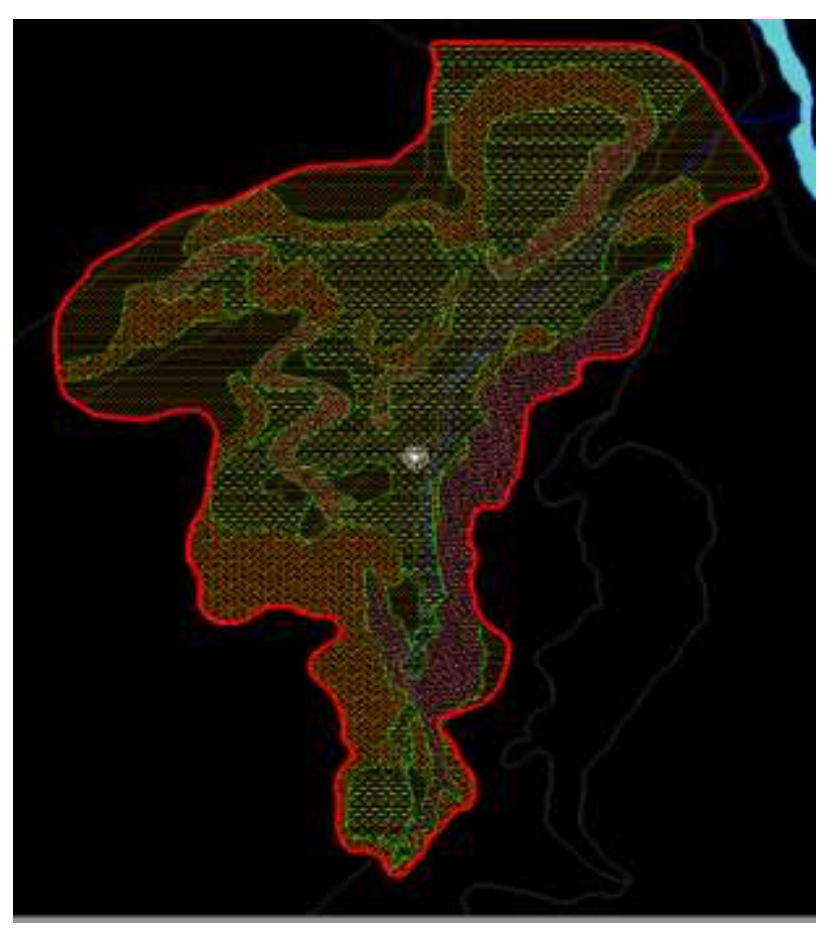

Gambar 8. Hasil pengeplotan seluruh area terhadap nilai nilai kelerengan.

Hasil klasifikasi yang telah dibuat dibuat skor seperti pada Tabel 5. Didapatkan skor 2 untuk daerah 
Tabel 5. Perpaduan Hasil Analisa, Skor dan Langkah yang harus dilakukan

\begin{tabular}{|r|l|l|c|c|c|l|l|}
\hline \multicolumn{2}{|c|}{ Luas Area } & Kelas & $\begin{array}{c}\text { Kemiringan } \\
\text { Lereng (\%) }\end{array}$ & Skor & Skor x Bobot (20) & RATING & Langkah \\
\hline $34.01 \mathrm{Ha}$ & $32.48 \%$ & Datar & $<8$ & 5 & 100 & Aman & \\
\hline $23.54 \mathrm{Ha}$ & $22.48 \%$ & Landai & $8-15$ & 4 & 80 & Sedang & Pemantauan \\
\hline $27.87 \mathrm{Ha}$ & $26.61 \%$ & Agak Curam & $16-25$ & 3 & 60 & Sedang-tinggi & Waspada \\
\hline $19.3 \mathrm{Ha}$ & $18.43 \%$ & Curam & $26-40$ & 2 & 40 & Tinggi & Peringatan \\
\hline $0 \mathrm{Ha}$ & $0 \%$ & Sangat Curam & $>40$ & 1 & 20 & Sangat Tinggi & Penutupan Area \\
\hline
\end{tabular}

Sumber : Hasil analisa

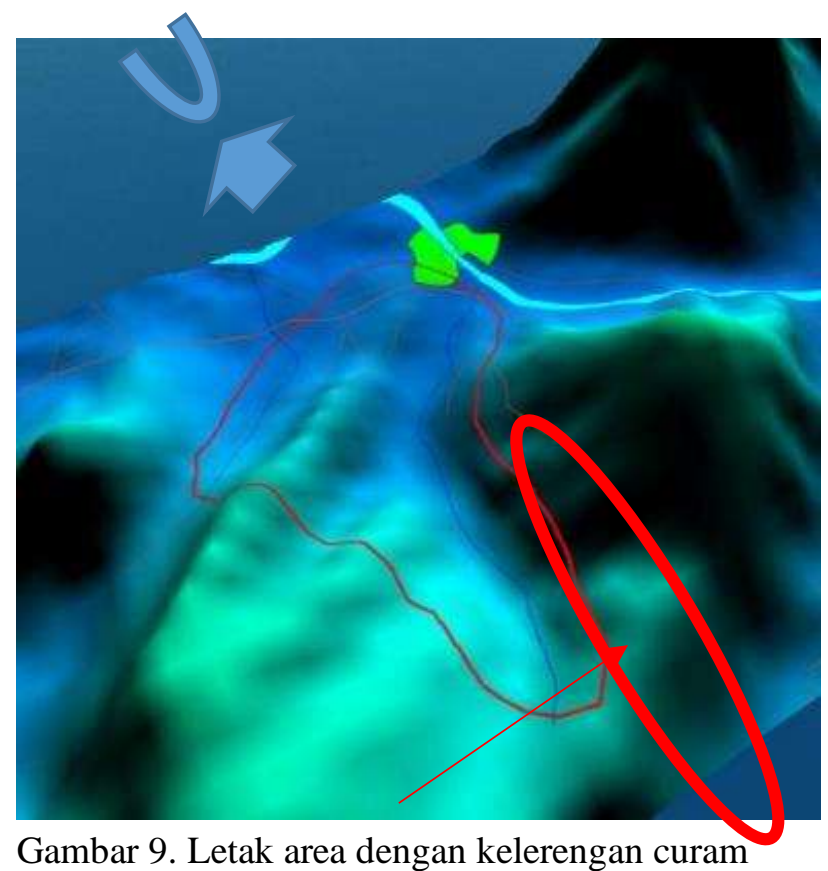

rating 40 yang artinya daerah tersebut daerah yang tinggi bahayanya. Langkah yang harus dilakukan adalah peringatan. Hal ini menjadi acuan kepada pemangku kebijakan di area tersebut bahwa daerah seluas $19,3 \mathrm{Ha}$ tersebut adalah daerah peringatan bahaya.

Area dengan kemiringan $25-45 \%$ di sisi bagian timur menempati luas 19,3 Ha disisi timur inilah yang menjadi sorotan pihak pemerintah daerah setempat.

Kemiringan yang landai berada di area tengah dan dekat dengan sungai dan beberapa bagian di area tengah dan utara. Area yang landai dan agak miring berada di area barat dan tenggara. Area area ini tidak mendapat perhatian khusus dari beberapa penduduk yang berada di sekitar maupun pemangku kepentingan terutama pemerintah daerah setempat.

Terdapat kemiringan lereng yang cukup mencolok pada kemiringan 25 hingga $45 \%$. Kemiringan ini berada pada area sisi timur dari cakupan penelitian. Area ini termasuk dalam klasifikasi curam (steep) menurut van Zuidam 1985. Menurut Sampurno 1984 termasuk klasifikasi miring terjal (sudut 22-55\%).

Hal utama yang menarik adalah proses kegiatan yang berlangsung sejak lama di daerah penelitian akibat penambangan batuan peridotit ini menjadikan area tersebut menjadi berbahaya dengan kemiringan lereng hingga $45 \%$.

Berdasarkan skor, hanya memiliki skor 2, sedangkan skor 2 mempunyai bobot hanya 40, sehingga ratingnya menjadi tinggi dan menurut klasifikasi merupakan area "peringatan" sebagai langkah yang dilakukan oleh pemerintah daerah setempat.

\section{KESIMPULAN DAN SARAN}

\section{Kesimpulan}

1. Perpaduan data lapangan menggunakan theodolith dengan Software Autocad Landesktop dan dihubungkan dari klasifikasi para pakar, hasilnya untuk rekomendasi akan bahaya pada area fokus penelitian.

2. Batu split atau batuan beku ultra basa atau peridotit, batuan terbentuk di area penelitian yang menjadi sorotan pemerintah daerah karena area penambangan menjadi daerah berbahaya.

3. Area penelitian berada didalam lahan milik Kementerian Kehutanan dengan luas 104,72 Ha yang telah dialihfungsikan menjadi area penambangan batu split.

4. Kelerengan area penelitian dipetakan dengan luas 104,72 Ha menggunakan unit Theodolith dan dipadukan dengan Software Autocad Landesktop 2009 menghasilkan 4 kategori kelerengan.

5. Fokus data pada kategori dengan kriteria Kelas-4 dengan luas area 19,3 Ha menempati 18,3\% dari 
luas area penelitian yang dipetakan adalah kategori curam. $12 \mathrm{Ha}$ berada di sisi timur yang merupakan area yang berbahaya dan menjadi sorotan pihak pemerintah daerah setempat.

6. $12 \mathrm{Ha}$ luas area yang berbahaya adalah kategori Lereng Curam. Berbahaya bagi kegiatan penambangan, baik penambangan manual maupun menggunakan peralatan berat.

7. Rating tinggi, sehingga area tersebut adalah area "peringatan" bagi siapa saja yang berada di daerah tersebut.

\section{Saran}

Penghentian atau mengalihkan lokasi penambangan pada area yang berbahaya dengan kategori Lereng Curam terutama pada area luas $12 \mathrm{Ha}$ yang berada di sisi timur lokasi penelitian.

\section{DAFTAR PUSTAKA}

Adi, D. 2015. Pengertian Ilmu Ukur Tanah menurut Benyamin Unwakoly. https://dekadisingaraja. blogspot.com/

Harjowigeno. 1995. Ilmu Tanah. PT Media Sarana Prakasa. Jakarta.

Puas, Darius. 2010. Jalan Dalam Langkah Land Dekstop and Civil Design, Penerbit Informatika - Bandung.

Sukandarrumidi. 2009. Bahan galian Industri, Yogyakarta, Gadjah Mada University Press.

Thornburry William D. 1969. Principles of Geomorphologi, Willey International, United States of America.

Zuidam. Van, R.A. 1983. “Guide to Geomorphologic Aerial Photographys Interpretation and Mapping”, Enschede.

Peta Rupa Bumi Lembar Martapura 1712-52 dan Lembar Aranio 1712-24 skala $1: 50.000$ Edisi 1991

Peta Geologi Lembar Banjarmasin 1712 Edisi 1995. 